\title{
MEMBONGKAR SANGKAR EMAS PASAR BEBAS MELALUI STRATEGI GACOAN
}

\author{
Elana Era Yusdita ${ }^{1}$, Anggie Riestanty ${ }^{2}$, Ardiyanto Darma Tantama ${ }^{3}$ \\ Universitas PGRI Madiun \\ elaradita@unipma.ac.id
}

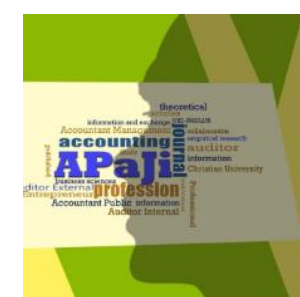

e-ISSN 2686-0058

p-ISSN 2715-7695

Informasi Artikel

Tanggal masuk

15 November 2019

Tanggal revisi

16 Desember 2019

Tanggal diterima

26 Januari 2020

Kata Kunci:

Strategic Management ${ }^{1}$

Management

Accounting $^{2}$

Accounting for Local

Wisdom ${ }^{3}$

\begin{abstract}
This study aims to uncover the practice of strategic management and management accounting that is not based on free markets. The awareness of local wisdom SMEs businesses is examined through phenomenology so that it can reveal the strategies used, then critical reviews are used to present other values in the strategy besides aiming at profits. The results showed that the first informant presented social value in doing business so he decided to group in doing business, while the second informant who was individualist preferred to break the supplier and distributor chains for higher margins. Both of them present love in determining the assets being sold, mapping the customer profile, and pricing. These bird traders do not recognize fixed assets and biological assets, there are only "gacoan" and "non-gacoan" criteria. This shows that not all management strategies and management accounting yield to the market and profits.
\end{abstract}

\begin{abstract}
Abstrak: Penelitian ini bertujuan untuk menguak praktik manajemen strategi dan akuntansi manajemen yang tidak berbasis pasar bebas. Kesadaran para pelaku bisnis UMKM berkearifan lokal diteliti melalui fenomenologi sehingga dapat mengungkapkan strategi yang digunakan, lalu tinjauan kritis digunakan untuk menghadirkan nilai lain dalam strategi selain bertujuan laba. Hasil penelitian menunjukkan bahwa informan pertama menghadirkan nilai sosial dalam berbisnis sehingga ia memutuskan untuk berkelompok dalam berbisnis, sedangkan informan kedua yang individualis lebih senang memutuskan rantai suplier dan distributor untuk margin yang lebih tinggi. Namun keduanya menghadirkan cinta dalam penentuan aset yang dijual, pemetaan customer profile, dan penetapan harga. Para pedagang burung ini tidak mengenal aset tetap dan aset biologis, hanya ada "gacoan" dan "non gacoan". Hal ini menunjukkan tidak semua manajemen strategi dan akuntansi manajemen menyerah kepada pasar dan laba.
\end{abstract}

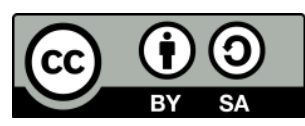

\section{PENDAHULUAN}

Selama ini semua strategi bisnis selalu mengusung tujuan akhir berupa keuntungan, entah lewat cara berlomba menjadi yang paling unik (Magretta, 2012), sampai mengubah intangible assets menjadi sesuatu yang bernilai tambah (Kaplan \& Norton, 2004). Sebuah bisnis yang menguntungkan lebih banyak dibahas daripada bisnis yang menyenangkan. Satu bisnis yang belum dibahas namun semakin marak adalah bisnis burung. 
Kegemaran memelihara burung telah lama dilakukan, bahkan sejak zaman penjajahan oleh Belanda (Iskandar, 2014). Kegemaran ini berkembang menjadi bisnis yang menjamur di Kota Madiun. Peternak dan pedagang merupakan pemeran utama majunya jual beli di bidang ini. Lokasi transaksi tidak hanya ada di pasar saja, namun dapat dijumpai di rumah peternak dan pedagang burung, bahkan beberapa sudah menggunakan forum jual beli daring. Bahkan bisnis ini berimbas kepada munculnya profesi yang dipandang cukup penting di Kota Madiun, yaitu juri lomba kicau burung. Dengan semaraknya lomba burung, maka banyak peternak burung baru yang merintis usaha, yang berimbas pada penghasilan pedagang burung dan pengrajin sangkar, hingga petani jagung untuk pakan burung (Rahmatika, 2017). Efek domino ini membentuk lingkaran simbiosis mutualisme antarprofesi di bidang ternak burung.

Hal unik dapat kita jumpai pada orang yang mengaku dirinya pedagang burung, beberapa bahkan menjadi peternak. Berbeda dengan peternakan biasa yang mengembangkan anakan lalu menjual ternak ketika siap panen, peternak dan pedagang burung mengalami ketidakpastian atas terjualnya hewan ternaknya. Titik panen bahkan menjadi bias saat mereka mencampuradukkan perdagangan dan kegemaran. Uniknya, beberapa dari mereka menggantungkan perekonomian keluarga dari perdagangan atau bahkan menjadikan ternak burung sebagai usaha sampingan untuk menunjang pemasukan utama sebagai pegawai tetap. Padahal, entitas yang menunjukkan orientasi kewirausahaan dan pasar dengan jelas dinilai dapat lebih sukses (Jones \& Sisay, 2014). Bukan tidak mungkin strategi yang dirancang suatu entitas berdasarkan pedoman akuntansi yang berlaku di suatu negara (Creţu, Creţu, \& Muscănescu, 2014). Dalam akuntansi, ada dua pilihan untuk penggolongan aset biologis, yaitu sebagai aset biologis yang bukan tanaman produktif dalam PSAK 69 atau sebagai tanaman produktif yang diperlakukan sebagai aset tetap dalam PSAK 16 (IAI, 2018).

Selama ini, penelitian yang dilakukan mengenai tipologi Miles \& Snow dan strategi Porter lebih mengarah kepada usaha menengah dan besar (misalnya (Gnjidi, 2014)). Yang keluar dari tema itu, berfokus pada penggunaan sosial media yang dipandang efektif bagi SMEs (misalnya Pentina \& Koh, 2012; Nobre \& Silva, 2014). Jones \& Sisay (2014) beranggapan bahwa sebenarnya tipologi Miles \& Snow lebih cocok dilakukan pada SMEs dibandingkan strategi milik Porter karena strategi Miles \& Snow beriorientasi terhadap cara entitas menanggapi perubahan lingkungan yang dinilai sesuai dengan sifat UMKM. Perbedaan di antara keempat strategi milik Miles \& Snow terletak pada fokus perusahaan, apakah untuk bertahan dengan harga produksi murah atau menyerang dengan inovasi atau tidak menutup kemungkinan gabungan keduanya dipakai. Tentunya hal ini tidak matching untuk SMEs yang diniatkan hobi dan berjualan sekaligus karena aset yang dimiliki bisa jadi ia simpan karena rasa sayang atau dijual karena tau unsur langka atau harga yang sedang naik. Jikalau masuk ke ranah strategi nonprofit, maka bahasan tidak sesuai karena pembahasan mengarah ke arah peningkatan kualitas layanan (misal Al-Tabbaa, Gadd, \& Ankrah (2013).

Ramainya bisnis ini di beberapa daerah, khususnya di Madiun, serta tidak masuknya bisnis berdasarkan kegemaran di dalam tipologi bisnis mendorong peneliti ingin meneliti strategi yang diterapkan dalam bisnis burung. Peneliti tidak dapat mengkhususkan penelitian pada pengembangbiakan atau perdagangan burung saja karena seringkali kedua jenis bisnis tersebut saling terkait dan tak dapat dipisahkan. Penelitian ini akan menggunakan fenomenologi kritis untuk mendalami kesadaran para pelaku bisnis sehingga dapat 
mengungkapkan strategi yang digunakan dan menghadirkan nilai lain dalam strategi selain bertujuan laba.

\section{METODE PENELITIAN}

Peneliti mencoba menghubungi beberapa pedagang dan peternak burung untuk membuat janji wawancara, namun beberapa di antaranya menolak dan yang lain tidak memberikan respon. Peneliti akhirnya langsung datang ke pasar untuk mewawancarai orang yang tampak berjualan burung di pasar. Peneliti berhasil mewawancarai dua orang. Satu orang merupakan pedagang burung yang memiliki tempat berjualan tetap di pasar lokal di Kota Madiun, sedangkan orang kedua merupakan teman orang pertama yang kebetulan ada di lokasi saat orang pertama diwawancarai. Informan kedua merupakan peternak sekaligus pedagang yang usahanya berlokasi di rumah. Lokasi wawancara adalah Pasar Srijaya, yaitu pasar hewan terbesar di Kota Madiun.

Wawancara terjadi tiga kali. Pada wawancara pertama, peneliti berbincang dengan kedua informan untuk mendapatkan informasi awal. Wawancara kedua dilakukan setelah analisis data pada hasil wawancara pertama, namun peneliti hanya menemukan informan pertama saja di tempat penelitian. Pada wawancara ketiga, peneliti menanyakan beberapa hal yang perlu didalami karena metode penelitian yang digunakan adalah fenomenologi yang mengupas kesadaran terdalam informan (Kamayanti, 2016), sekaligus bertemu dengan informan kedua. Hasil wawancara dari tiga kali pertemuan itulah yang dianalisis menjadi sebuah kesimpulan menurut masing-masing informan, mengingat jenis burung yang diperdagangkan oleh keduanya berbeda. Langkah-langkah yang ditempuh dalam menganalisis data dalam fenomenologi adalah noema, noesis, epoche (bracketing), intentional analysis, dan eidetic reduction (Kamayanti, 2016). Tapi peneliti tidak berhenti pada eidetic reduction karena ingin memunculkan nilai dalam manajemen strategi yang selama ini belum ada, tidak cukup mengakui kebenaran menurut "Aku". Oleh karena itu, peneliti mengekstensi fenomenologi ke ranah kritis, yaitu membawa nilai menurut "Aku" untuk membongkar tipologi strategi sehingga muncul sebuah bangunan strategi baru berdasarkan kearifan lokal. Ekstensi ini dimungkinkan karena sudah terdapat evolusi fenomenologi dalam bentuk postfenomenologi dan fenomenologi tauhid (Kamayanti, 2016).

\section{HASIL DAN PEMBAHASAN}

\section{Memilih aset: yang diminati pasar atau diri sendiri?}

Berdagang ternyata boleh jadi sumber pendapatan utama, tapi laba belum tentu menjadi tujuan utama dari strategi manajerial yang dilakukan oleh pedagangnya. Langkahlangkah yang dilakukan oleh pemilik usaha merupakan perwujudan langkah mencapai tujuan. Jika masuk dalam ranah konvensional, pengendalian manajemen lekat dengan pengukuran kinerja finansial dan nonfinansial dengan tujuan pengoptimalan nilai pemegang saham dan pertanggungjawaban kepada pemegang kepentingan yang terdiri dari pasar modal, pasar produk, dan pasar faktor (Anthony \& Govindarajan, 2004). Ada hal lain yang tidak ditangkap oleh praktek yang dituliskan di dalam buku manajemen strategi yang saat ini beredar. Contohnya dalam penelitian ini, informan secara tidak sadar mengutarakan niatnya dalam memelihara burung, yaitu untuk kegemaran sekaligus bisnis.

"Memang kita ini cuma hobby, [hobby yang disalurkan jadi dagang]." 
Ia memilih untuk berdagang lovebird dan muray karena hobinya memelihara jenis ini. Informan pertama menyatakan bahwa ia merupakan peternak dan pedagang burung sekaligus. Pekerjaan ini merupakan pekerjaan utama sehingga informan sampai memiliki kios di pasar Srijaya. Jika dilihat dari analisis data wawancara, ia memilih fokus lovebird dan muray karena hobi, setelah itu informan baru menyediakan beberapa macam lovebird dan muray berdasarkan customer profile.

“...kalo [lovebird] itu [ada yang mencari warna], ada yang mencari [ngekek]. Kalo nyari warna kan biasane dari [impor] langsung, harga jualnya harganya standarnya itu sudah ada."

Sedangkan, informan kedua merupakan peternak burung muray selama 10 tahun terakhir, namun hanya sebagai pekerjaan sampingan. Informan menjual ternaknya ke pedagang di pasar burung dan menjual langsung ke perorangan. Informan memilih jenis muray karena peminatnya banyak di Madiun dan harganya sudah bagus meskipun tidak ikut lomba. Selain itu, jika dibandingkan dengan lovebird yang bertelur tiga bulan sekali, murray dapat bertelur sebulan sekali. Alasan ini menyiratkan si pedagang bertujuan marjin karena tidak ingin terlalu terlibat pada perkumpulan karena merasa tidak ada kesenangan tersendiri untuk berkecimpung dalam kelompok dan mengikuti lomba. Informan kedua beralasan menghindari pengepul dalam perkumpulan untuk mendapatkan margin yang lebih banyak. Penggunaan kata "rugi" pada wawancara menegaskan hal ini.

"Saya tidak ikut perkumpulan, tapi jual sendiri mbak...kalo dijual di situ [rugi]."

Saat ditanyakan maksud rugi itu, pedagang kedua menyatakan yang dimaksud rugi adalah tidak dapat menjual langsung kepada konsumen akhir.

"Hubungannya sama pengepul. Nggak dijual sendiri kan."

Untuk memuluskan tujuannya, bahkan pedagang ini membuat peternakan yang anakannya dapat dibiakkan sendiri maupun dijual kepada orang lain. Bahkan, informan kedua membuka sistem inden untuk mereka yang berminat membeli anakan yang belum menetas.

\section{Pemetaan customer profile}

Penentuan customer profile merupakan salah satu langkah dalam strategi kewirausahaan, yaitu mengetahui seberapa cocok dan bernilai produk kita bagi konsumen (Widjaja \& Wirananta, 2017). Hal ini berbeda dengan produk yang dianalisis dari sudut pandang mengalahkan pesaing. Hasil analisis data menunjukkan informan pertama memiliki dua customer profile. Customer profile yang pertama adalah orang rumahan, yaitu konsumen yang menikmati keindahan burung tanpa niat berlomba. Sedangkan customer profile kedua adalah peserta lomba atau kontes burung. Masing-masing dari jenis customer profile memiliki preferensi sendiri dalam memilih jenis burung yang disukai. Orang rumahan lebih suka menikmati warna lovebird. Untuk memenuhi permintaan itu, pedagang akan mencari kombinasi warna yang bagus, begitupun peternak yang akan mencari anakan dengan warna bagus. Orang yang menjadi peternak otomatis akan sekaligus menjadi pedagang karena pasti menjual hasil ternakannya. Peternak dan pedagang yang menitikberatkan pada warna akan 
memilih impor, sehingga imbasnya adalah sudah ada standar harga tertentu. Menurut informan pertama, dia tidak perlu menciptakan sendiri harga dengan melatih atau mengikutkan lomba.

Sedangkan, peserta lomba akan mencari burung yang dapat dijadikan gacoan atau pegangan kontes. Burung dengan kicau berkualitas akan memiliki harga lebih tinggi saat memenangkan lomba. Menariknya adalah pedagang burung dapat menjadi peserta lomba. Dia tidak akan menjual secara bebas dan terbuka sang gacoan layaknya burung jenis lainnya. Informan pertama menyatakan bahwa dia meletakkan burung gacoan di rumah daripada dipajang di pasar. Calon pembeli yang tertarik pasti akan menghubungi informan pertama di tempat lomba atau datang langsung ke rumah. Hal ini berarti daya jual burung gacoan naik tanpa adanya promosi dan dipajang di pasar. Kontes itu sendiri menjadi sarana promosi. Namun dalam hal ini informan pertama memang tidak bertujuan utama menjual burung gacoannya, karena dia menganggap mengikutkan lomba merupakan kesenangan tersendiri. Berbeda dengan burung lovebird yang memiliki keunggulan warna (bukan untuk lomba kicau), burung lovebird yang digunakan untuk lomba didapatkan dari pasar lokal atau dengan kata lain tidak butuh impor. Pada saat membeli anakan burung, informan pertama akan memisahkan antara burung yang berkualitas dan tidak berkualitas suaranya. Suara lovebird ini disebut ngekek. Burung yang berkualitas akan dibawa pulang untuk dilatih. Strategi yang diterapkan pedagang ini sebenarnya merupakan upaya untuk membiarkan gacoan istirahat hingga memiliki tenaga cukup pada saat bertanding.

Sedangkan burung yang tidak memiliki kicauan dengan kualitas bagus akan diperlakukan sebagai pelatih burung gacoan. Burung gacoan membutuhkan teman untuk berlatih dan meniru ngekek. Peluang ini dimanfaatkan pedagang burung lovebird untuk menyediakan burung non gacoan. Burung jenis ini tidak memiliki daya jual tinggi sehingga akan dipajang di pasar. Artinya setiap burung, baik gacoan maupun bukan gacoan memiliki perannya sendiri-sendiri dan semuanya bertujuan akhir untuk lomba burung. Berdasarkan hal ini peneliti memutuskan nama strategi yang digunakan oleh informan disebut Gacoan Strategy. Pemetaan tipe burung yang dijual secara ringkas ditunjukkan pada Gambar 1.

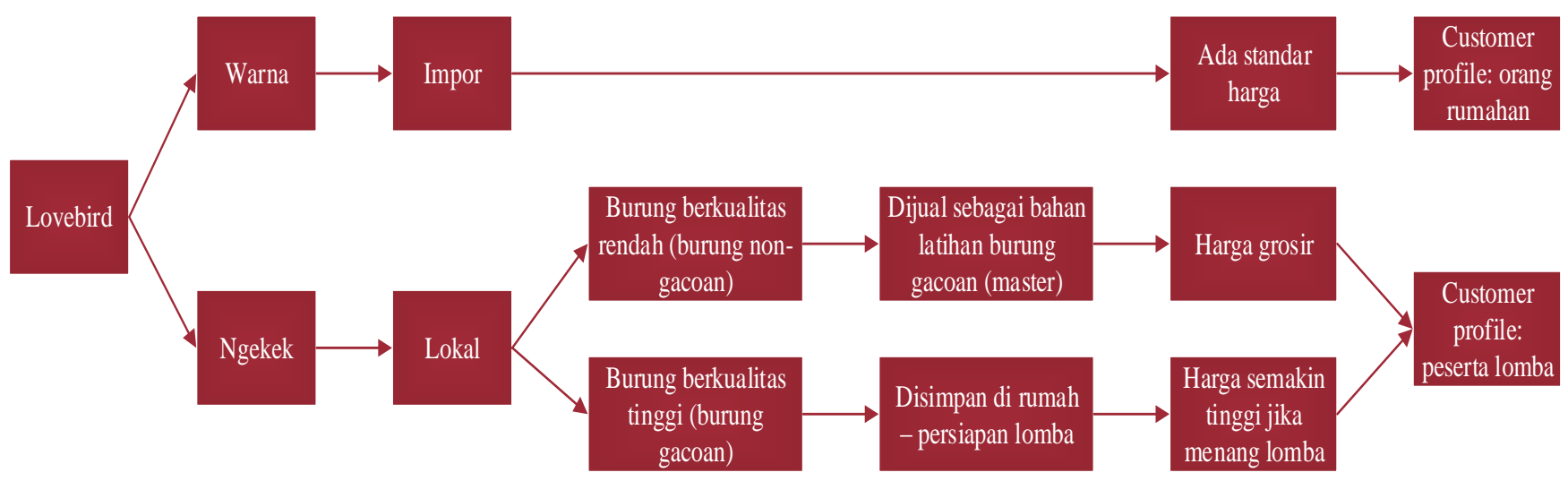

Gambar 1. Pemetaan Tipe Burung Lovebird

Informan pertama juga memiliki aset biologis jenis lain, yaitu burung muray. Perbedaan jenis burung juga akan berimbas pada perbedaan karakteristik dan strategi penjualan. Menurut informan pertama, customer profile untuk pembeli burung muray adalah 
peserta lomba dan peternak. Peserta lomba akan mencari burung muray yang ekornya tidak begitu panjang namun dapat bersuara bagus. Kriteria suara indah dapat ditentukan oleh tiga hal, yaitu power, irama, dan keantengan. Burung yang dijadikan gacoan dan berkualitas bagus akan disimpan oleh informan di rumah. Sedangkan, informan pertama menyediakan muray dengan ekor panjang untuk orang rumahan yang ingin memelihara burung untuk dinikmati keindahannya.

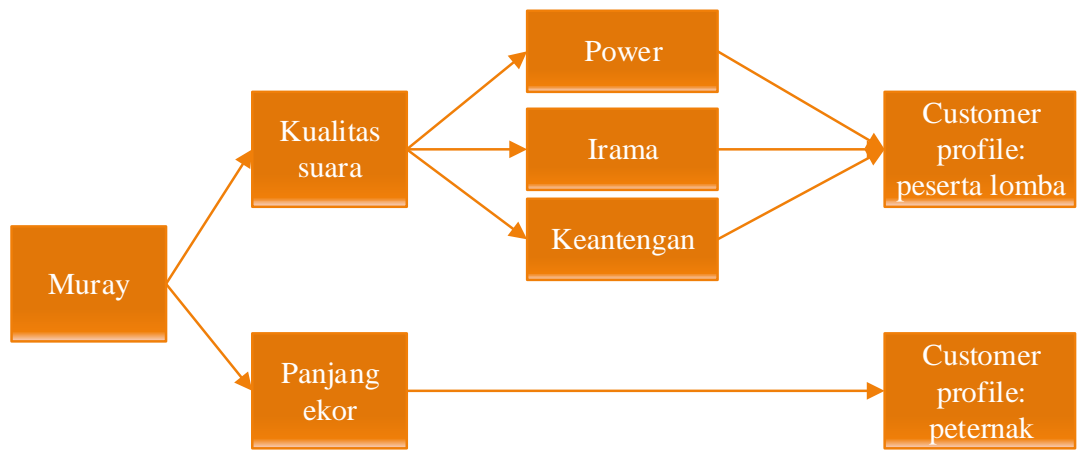

Gambar 2. Pemetaan Tipe Burung Murray

Mengenai burung muray, informan kedua lebih spesifik membahas strategi yang diterapkan pada burung tipe ini. Informan kedua lebih memilih menjadi peternak muray dengan sasaran pembeli orang rumahan dan orang yang mengikuti lomba. Beda dengan informan pertama, informan kedua tidak mau mengikuti lomba dan perkumpulan. Hal ini terjadi karena beberapa sebab. Pertama, dia ingin menentukan harga jualnya sendiri tanpa melalui pengepul di dalam perkumpulan. Kedua, karena dia tidak memiliki waktu untuk melatih muray. Dia memilih jenis muray untuk ternakan karena masa bertelurnya lebih singkat daripada lovebird yang tiga bulan sekali, yaitu sebulan sekali. Informan kedua merasa burung muraynya pasti laku, oleh karena itu dia lebih memilih strategi menjual ternaknya dengan harga tinggi daripada harus laku setiap hari dengan harga murah. Dia menerapkan sistem inden untuk calon pembeli yang belum mendapat anakan karena belum menetas. Oleh karena itu, resiko yang dihadapi oleh informan adalah gagal tetas dan sakitnya ternak, bukan kalah lomba.

\section{Makna Komunitas dan Penetapan Harga}

Perkumpulan memainkan peranan penting dalam bisnis burung karena berfungsi untuk berbagi informasi antar pedagang dan peternak. Sebuah produk nyata yang muncul dari perkumpulan ini adalah adanya pengepul dan pengadaan lomba burung. Hal ini menjadi daya tarik tersendiri karena dapat mengumpulkan orang dengan kegemaran sama dan dapat meningkatkan harga burung. Dua tujuan ini yang dicari oleh informan pertama. Informan mengaku mengikuti perkumpulan bahkan sebelum berdagang burung, yaitu pada tahun 2008 . Tujuan utama informan mengikuti perkumpulan adalah untuk senang-senang, memperoleh informasi kegiatan lomba, dan untuk menjalin hubungan antarpedagang. Untuk tujuan tersebut, informan mengikuti perkumpulan "pemain". Tujuan atau profesi seseorang di dalam lomba burung menentukan jenis perkumpulan apa yang diikuti. Selain perkumpulan "pemain", ada perkumpulan untuk para juri lomba. Informan pertama memaknai "perkumpulan" sebagai sarana bersenang-senang dan usaha menaikkan harga burung. Ia 
melihat perkumpulan sebagai sesuatu yang penting di dalam kegiatan memelihara dan jual beli burung.

"Ya buat [seneng], buat ketemu sama temen, silaturahmi gitu. Ya kita kan [hobi kan kumpul] sama temen eeer apa itu ya itulah biasanya menjalin hubungan sesama yaa relationship. Yaa buat seneng lah, [ngikuti event event]."

Informan kedua menurut hasil trianggulasi memang dulu pernah mengikuti perkumpulan dan lomba, namun kini jarang bergabung di perkumpulan bahkan tidak pernah mengikuti lomba. Informan kedua mengenali adanya pengepul yang dianggap mengancam independensinya dalam menetapkan harga. Informan kedua yang lebih meniatkan usahanya untuk marginpun memilih mengusahakan anakan sendiri sampai memutus rantai perdagangan dengan menjual sendiri burung hasil ternaknya ke pedagang di pasar atau konsumen rumahan langsung. Informan kedua memaknai "perkumpulan" sebagai sesuatu yang merugikan karena akan mengurangi margin yang ia dapat. Ia memandang perkumpulan dari perspektif bisnis.

\section{Refleksivitas: Apakah strategi selalu muncul untuk mencapai laba?}

Berdasarkan hasil wawancara, saat burung tersebut kalah dalam kontes, informan pertama tidak merasa rugi karena mencari untung bukanlah yang utama. Kami terinspirasi dari tulisan (Kurniawan, Mulawarman, \& Kamayanti, 2014) bahwa dalam aset biologis terdapat religious utility, social utility, dan economical utility. Jika penelitian tersebut membahas dari konteks akuntansi, maka penelitian kali ini membahas dari sisi manajemen strategi, bahwa seseorang dapat berdagang dengan mengusung kepentingan ekonomi dan sosial. Strategi yang diterapkan oleh informan pertama misalnya, ia memutuskan untuk bergabung pada perkumpulan untuk membeli anakan dan mengikuti lomba, memilih jenis burung yang ia gemari, lalu menjual apa yang dibutuhkan oleh penggemar burung untuk melatih "gacoan". Ia tidak menjadikan "gacoan" menjadi barang dagangan utama karena baginya "gacoan" adalah aset yang tak ternilai. Hanya pada saat tertentu, si informan melepas burungnya untuk dijual. Hal ini tidak dapat ditangkap manajemen strategi pada umumnya. Informan pertama tak membutuhkan strategi menurut Miles \& Snow serta Porter. Informan pertama hanya membutuhkan kesenangan saat memelihara burung dan pemenuhan kebutuhan sehari-hari saja, bukan pemaksimalan keuntungan.

Meskipun tidak tercakup dalam tipologi strategi Miles \& Snow serta Porter, informan kedua cenderung individualis. Ia menerapkan strategi memutus rantai distribusi penjualan burung untuk keuntungan yang lebih besar, bahkan menghasilkan anakan sendiri. Ia memilih jenis muray lebih karena ada peminatnya dan tidak perlu ikut lomba. Ia justru memandang perkumpulan dan lomba sebagai sesuatu yang memberatkan. Hal ini ditempuh karena ia memandang beternak dan berdagang burung hanya sebagai pekerjaan sampingan, jadi tidak perlu mencari nilai tambah atau manfaat sosial.

Jika dipandang dari sisi nilai uang, strategi informan kedua yang lebih bagus. Namun jika dipandang dari seberapa banyak nilai yang didapatkan, maka strategi informan pertama yang lebih "kaya" karena ia menikmati usaha yang ia lakukan dan merepresentasikan sebagai mahluk sosial. Hal ini bertolak belakang dengan anggapan pasar bebas merupakan hak setiap orang untuk bersaing, memicu kreativitas dan pada akhirnya kewirausahaan 
dipandang sebuah cara untuk mencapai kesejahteraan ${ }^{1}$. Padahal kata sejahtera di sini hanya berlaku pada segelintir orang yang berhasil memenangkan persaingan, sedangkan mereka yang kalah akan keluar dari arena atau dikuasai oleh pemenang, sehingga mau tidak mau akan tercipta jurang di sini (Patomäki, 2017). Untuk melalui jurang pemisah itu diperlukan kompetisi yang berujung pada peperangan, sehingga diperlukakan strategi (Patomäki, 2017). Sampai pada titik ini, mata kuliah berjudul manajemen strategi yang diajarkan dari kelas ke kelas akuntansi dan manajemen justru mengarahkan pola pikir peserta didik untuk siap berperang karena adanya "jurang pemisah" saat berbinis. Padahal pada bisnis burung, justru para pelaku bertahan tanpa diversifikasi produk dan persaingan karena mereka menganggap bisnis adalah kesenangan, bukan persaingan. Aset yang dipilihpun berasal dari kegemaran masing-masing, tidak menyerahkan diri sepenuhnya kepada permintaan pasar. Mereka justru menyimpan burung berkualitas bagus di rumah dan tidak sepenuhnya diniatkan untuk dijual karena rasa sayang terhadap "gacoan" menurut informan pertama dan "indukan" menurut informan kedua. Pasar bebas terbentuk dari permintaan dan penawaran yang sebebasbebasnya, yang justru menjadi "sangkar emas" bagi para "pemenang". Para pemenang hanya mengenal mengenal kesejahteraan secara materi, bagian terluar dari lingkaran kesejahteraan setelah kesejahteraan mental dan spiritual (Triyuwono, 2015). Itulah penjara yang harus dibongkar!

\section{KESIMPULAN}

Peneliti menemukan informan pertama menghadirkan kesenangan di dalam bisnis dengan menggabungkan kegemaran, kebersamaan dalam perkumpulan, dan pemenuhan kebutuhan sehari-hari. Strategi yang digunakan adalah mengikuti perkumpulan dan lomba, pemenuhan kebutuhan pribadi sekaligus konsumen dalam memilih aset dalam berdagang, dan justru tidak memamerkan si burung juara atau "gacoan" karena tidak diniatkan untuk dijual. Informan kedua justru tidak ingin keasyikan bisnisnya diganggu pihak lain, jadi ia berperan sebagai suplier dan distributor bagi dirinya sendiri, namun tetap ada unsur kegemaran dan menyimpan burung yang berkualitas bagus untuk dirinya sendiri. Peneliti tidak menemukan unsur persaingan pada pasar bebas di bisnis ini karena semuanya dimulai dengan kecintaan pada burung dan bahkan diniatkan menjalin hubungan baik dengan komunitas. Ini adalah bukti bahwa "sangkar emas" pasar bebas dapat dibongkar menggunakan strategi gacoan.

Kelemahan penelitian ini adalah peneliti hanya sampai pada tataran kesejahteraan mental atau manfaat sosial dari berbisnis, belum dapat mengekstensi sampai pada spiritualitas. Saran untuk penelitian selanjutnya adalah berorientasi meneliti sampai ke religios utility dari sebuah bisnis berkearifan lokal dan jika dimungkinkan dapat mendalami pasar perdagangan burung ini melalui etnometodologi.

\section{DAFTAR PUSTAKA}

Al-Tabbaa, O., Gadd, K., \& Ankrah, S. (2013). Excellence models in the non-profit context: Strategies for continuous improvement. International Journal of Quality and Reliability

\footnotetext{
${ }^{1}$ Disampaikan oleh Bertina Solinger selaku Direktur International Academy for Leadership (IAF) dalam acara Promoting Enterpreneurship and Open Markets, pernyataan dikutip dari https://indonesia.fnst.org/content/mengapa-perlu-pasar-bebas
} 
Management, 30(5), 590-612. https://doi.org/10.1108/02656711311315521

Anthony, R. N., \& Govindarajan, V. (2004). Management Control System. New York: The McGraw-Hill Companies.

Creţu, R. C., Creţu, R. F., \& Muscănescu, A. (2014). Comparative Analysis of Strategic and Tactical Decisions in Agriculture under the IAS 41 Standard in the Context of the Emerging Markets. Procedia Economics and Finance, 15, 1641-1646. https://doi.org/10.1016/S2212-5671(14)00635-2

Gnjidi, V. (2014). Researching the dynamics of Miles and Snow's strategic typology. Management, 19(1), 93-118.

IAI. (2018). Standar Akuntansi Keuangan Efektif per 1 Januari 2018. Jakarta: Ikatan Akuntan Indonesia.

Iskandar, J. (2014). Dilema Antara Hobi dan Bisnis Perdagangan Burung Serta Konservasi Burung. Chimica et Natura Acta, 2(3), 180-185.

Jones, R., \& Sisay, S. (2014). Strategic Management in SMEs: An Orientation Approach. In K. Todorov \& D. Smallbone (Eds.), Handbook of research on strategic management in small and medium enterprises (pp. 1-21). Hershey.

Kamayanti, A. (2016). Metodologi Penelitian Kualitatif Akuntansi: Pengantar Religiositas Keilmuan. Jakarta: Yayasan Rumah Peneleh.

Kaplan, R. S., \& Norton, D. P. (2004). Strategy Maps: Converting Intangible Assets into Tangible Outcomes. Boston: Harvard Business School Publishing.

Kurniawan, R., Mulawarman, A. D., \& Kamayanti, A. (2014). Biological assets valuation reconstruction: A critical study of IAS 41 on agricultural accounting in Indonesian farmers. Procedia - Social and Behavioral Sciences, 164(August), 68-75. https://doi.org/10.1016/j.sbspro.2014.11.052

Magretta, J. (2012). Understanding Michael Porter: Panduan Paling Penting tentang Kompetisi dan Strategi. Yogyakarta: ANDI.

Nobre, H., \& Silva, D. (2014). Social Network Marketing Strategy and SME Strategy Benefits. Journal of Transnational Management, 19(2), 138-151. https://doi.org/10.1080/15475778.2014.904658

Patomäki, H. (2017). Capitalism : Competition, Conflict, Crisis. Journal of Critical Realism, 16(5), 537-543. https://doi.org/10.1080/14767430.2017.1332807

Pentina, I., \& Koh, A. C. (2012). Exploring social media marketing strategies in SMEs. International Journal of Internet Marketing and Advertising, 7(4), 292. https://doi.org/10.1504/IJIMA.2012.051613

Rahmatika, D. (2017, October 21). Efek Domino bagi Peternak, Perajin Sangkar, hingga Petani Jagung. Jawa Pos, p. 25.

Triyuwono, I. (2015). Akuntansi Malangan: Salam Satu Jiwa dan Konsep Kinerja Klub Sepak Bola. Jurnal Akuntansi Multiparadigma, 6(2), 290-303.

Widjaja, A. P., \& Wirananta, A. (2017). Ledakkan Ide Bisnismu Dalam Sembilan Dalam Sembilan Minggu. Jakarta: Elex Media Komputindo. 